\title{
Coronavirus and Homo Sapiens
}

\author{
Pooja Natarajan ${ }^{1}$ Muralidhar Kanchi ${ }^{1}$ Vikneswaran Gunaseelan ${ }^{2}$ Alben Sigamani ${ }^{2}$ \\ James Harmon ${ }^{3}$ Kumar Belani ${ }^{4}$
}

${ }^{1}$ Department of Anaesthesiology and Critical Care, Narayana Institute of Cardiac Sciences, Narayana Hrudayalaya, Bangalore, Karnataka, India

${ }^{2}$ Department of Research, Narayana Health City, Narayana Hrudayalaya Limited, Bangalore, Karnataka, India

${ }^{3}$ Department of Surgery, University of Minnesota, Minneapolis, Minnesota, United States

${ }^{4}$ Department of Anesthesiology, University of Minnesota, Minneapolis, Minnesota, United States

J Card Crit Care

\author{
Address for correspondence Muralidhar Kanchi, MD, FIACTA, \\ FICA, MBA, FASE, Department of Anaesthesiology and Critical Care, \\ Narayana Institute of Cardiac Sciences, Narayana Hrudayalaya Health \\ City, Bommasandra Industrial Area, Anekal taluk, \\ Bangalore 560 099, Karnataka, India \\ (e-mail: muralidhar.kanchi.dr@narayanahealth.org).
}

\begin{abstract}
Keywords

- antiviral treatment

- corona virus spike protein

- cytokine storm

The Spanish influenza pandemic of 1918 globally claimed death between 50 and 100 million lives. In India, it was referred to as "The Bombay Fever," and accounted for a fifth of the global death toll at that time. The current outbreak of the novel coronavirus disease 2019 (COVID-19), a new human-infecting beta coronavirus, has demonstrated that the size of an organism does not reflect on its ability to affect almost an entire human population. COVID-19, first detected in December 2019 in Wuhan, China, that spread rapidly worldwide. In humans, this disease ranged from flu-like symptoms to severe acute hypoxic respiratory failure. By appearance, this virus closely related to two bat-derived severe acute respiratory syndrome (SARS) coronaviruses. Although bats were likely the original host, animals sold at the Huanan seafood market in Wuhan might have been the intermediate host that enabled the emergence of the virus in humans. Under the electron microscope, the severe acute respiratory syndrome-coronavirus-2 (SARS-CoV-2) virus grips its receptor tighter than the virus behind the SARS outbreak in 2003 to 2004. The viral particle docks onto the angiotensin-converting enzyme 2 (ACE2) receptor and initiates viral entry. This review discusses the various aspects of the SARS-CoV-2 virus, its structure, pathophysiology, mechanism of interaction with human cells, virulence factors, and drug involved in the treatment of the disease.
\end{abstract}

\section{Introduction}

A novel variety of coronavirus, the severe acute respiratory syndrome-coronavirus-2 (SARS-CoV-2) virus, reported late in 2019 from Wuhan, Central China, has now globally spread with ruthless speed. ${ }^{1}$ It has expressed itself as a pandemic in our planet at all continents except Antarctica. The SARS$\mathrm{CoV}-2$ virus has been solely responsible and far exceeded the number of lives lost within a short period when compared to the 1919 pandemic and has had a significantly greater global economic impact. ${ }^{2}$ The World Health Organization (WHO) informed that the coronavirus pandemic is "defining global health crisis of our time," and has revealed the best and worst in humanity. On March 22, 2020, Mr. Narendra Modi, the Prime Minister of India, highlighted the scale of the challenge as follows: "Even World Wars I and II didn't affect as many countries as the coronavirus has done." SARS-CoV-2, the causative organism, is the name given to this virus, it is an enveloped RNA beta coronavirus that among other manifestations causes the respiratory disease called novel coronavirus disease 2019 (COVID-19; - Fig. 1). Coronaviruses are a family of viruses, named for the crown-like effect created by spikes on their surface, which are surface proteins that help them invade human cells. Similar coronaviruses cause
DOI https://doi.org/ $10.1055 / \mathrm{s}-0040-1716634$ ISSN 2457-0206.
(C2020 Official Publication of The Simulation Society (TSS), accredited by International Society of Cardiovascular Ultrasound (ISCU).
License terms

(®) $\Theta \circledast$ 
the common cold. What we're dealing with now is a new, or novel coronavirus called SARS-CoV-2 that is effectively transmitted between humans and can cause a wide range of clinical conditions ranging from asymptomatic to a fatal infection in both adults and children. ${ }^{3}$

\section{Structure of Coronavirus}

Coronaviruses, a large family of viruses, have crown-like appearance due to protein spikes on their surface that help the virus to invade human cells. Coronaviruses belong to the family coronaviridae in the order nidovirales ${ }^{1,4}$ and are classified into four groups: alpha, beta, gamma, and the delta coronavirus. Alpha- and beta-coronaviruses infect mammals, gamma-coronaviruses infect avian species, and delta-coronaviruses infect both mammalian and avian species ( - Fig. 1). The examples of the alpha-coronaviruses include human coronavirus NL63 (HCoV-NL63), porcine transmissible gastroenteritis coronavirus (TGEV), porcine epidemic diarrhea coronavirus (PEDV), and porcine respiratory coronavirus (PRCV). Beta-coronaviruses include SARS-CoV-1 and -2, MERS-CoV (Middle East respiratory syndrome-coronavirus), bat coronavirus HKU4, mouse hepatitis coronavirus (MHV), bovine coronavirus (BCoV), and human coronavirus OC43. Gamma- and delta-coronaviruses include avian infectious bronchitis coronavirus (IBV) and porcine delta-coronavirus (PdCV). Coronaviruses are remarkably large, enveloped, positive-stranded RNA (ribosomal nucleic acid) viruses, and have the most voluminous genome, ranging from 27 to $32 \mathrm{~kb} .{ }^{4}$ The nucleocapsid helical protein encloses the genome and is further surrounded by an envelope. The envelope has three

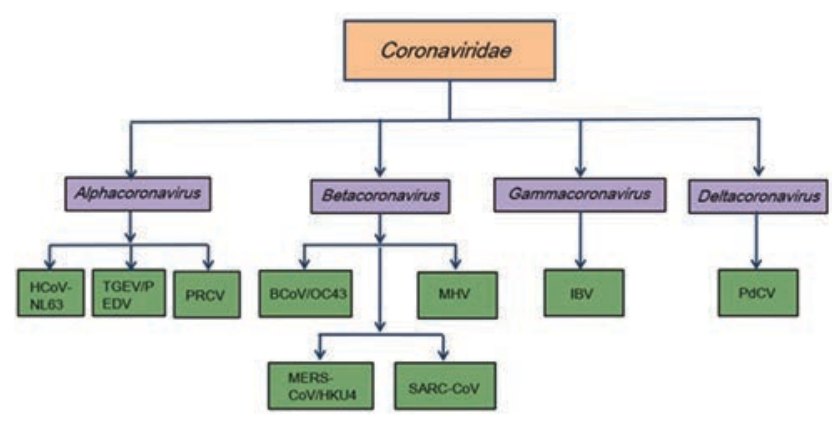

Fig. 1 Classification of coronaviruses. structural proteins, namely, membrane $(M)$, envelope (E), and spike (S) proteins (-Fig. 2A). The $\mathrm{M}$ and E proteins facilitate viral assembly, whereas $S$ protein is responsible for the viral attachment and entry into host cells. The S structural protein forms substantial protrusions from the virus surface, giving coronaviruses the look of having crowns (corona), is a key determinant of viral host response and is a major facilitator of the host-immune response. ${ }^{1}$

\section{The Life Cycle of SARS-COV-2}

The invasion begins when the $S$ protein binds to the host cellular ACE2 receptor. Binding triggers a conformation change in the $S$ protein that leads to viral envelope fusion with the host cell membrane through the endosomal pathway. SARSCoV-2 then releases RNA into the host cell ( - Fig. 3 ). Genome RNA is translated into viral replicating polyproteins pp1a and pp1ab that are then broken into smaller products by viral proteinases. The breakdown reaction produces a collection of subgenomic mitochondrial RNAs (mRNAs), by interrupted transcription and transformation into relevant viral proteins. Viral proteins and genomic RNA are collected into virions in the endoplasmic reticulum (ER), and golgi apparatus, and then transported via vesicles which are released from the infected host cell. The SARS-CoV2 S protein has three segments: a large ectodomain, a single-pass transmembrane anchor, and a short intracellular tail. A receptor-binding subunit S1 and a membrane-fusion subunit S2 form the ectodomain. Electron microscopy (EM) studies indicate that the spike is like a clove-shaped trimer with three S1 heads and a trimeric S2 stalk. ${ }^{6-11}$ When the virus enters the host cell, the S1 head binds to a receptor on the host cell surface, attaching the virus, enabling the S2 stalk to connect with the host and viral membranes, allowing the viral genomes into the host cells ( - Fig. 2B). These crucial initial steps during coronavirus infection, namely, receptor binding and membrane fusion are primary targets for human therapeutic interventions.

\section{Coronavirus and Receptor Binding}

Coronaviruses demonstrate a pattern of receptor recognition. ${ }^{10}$ The alpha-coronavirus HCoV-NL63 and the beta corona SARS-CoV viruses, both recognize a zinc peptidase in

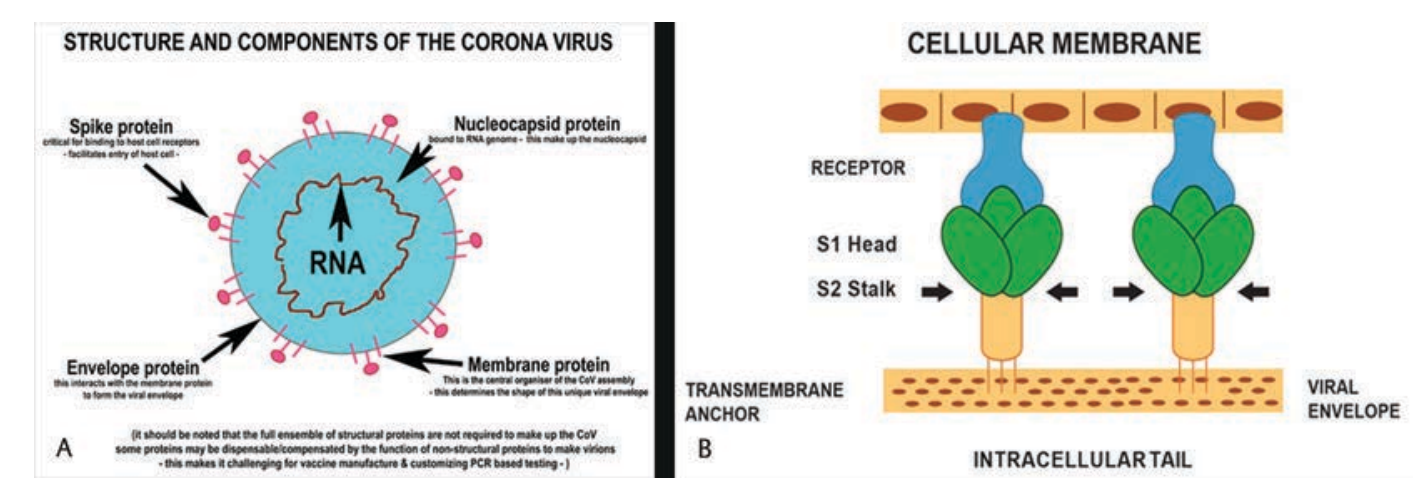

Fig. 2 Structure and components of coronavirus: (A) membrane, envelope, nucleocapsid, and spike proteins; (B) host cell surface and mechanism of entry of the viral genome into host cell. 


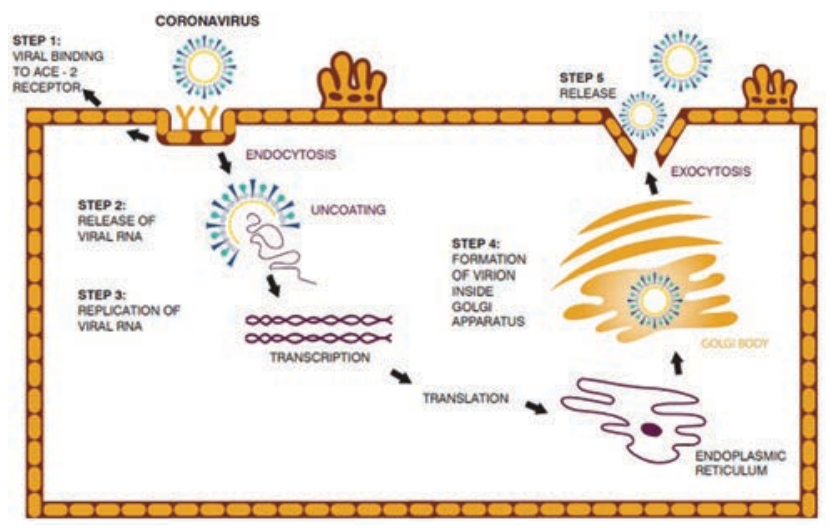

Fig. 3 The life cycle of severe acute respiratory syndrome-coronavirus-2. ACE2, angiotensin-converting enzyme 2.

the ACE2 receptor. The SARS-CoV-2 gains access into the cells by binding to the ACE2 receptor. Two binding hot spots have been identified on human ACE2: ACE2 residues Lys31 and Lys353. ${ }^{11-18}$ These two hotspots contribute significantly to virus-receptor binding. The coronavirus exists in two distinct configurations: (1) prefusion trimeric spike containing three receptor-binding $\mathrm{S} 1$ heads and a trimeric membrane-fusion S2 stalk and (2) postfusion trimeric S2 which is a six-helix bundle with exposed fusion peptides. A variety of triggers regulate the transition of the spikes from the prefusion to the postfusion arrangements. Receptor attachment and membrane fusion are critical determinants of the host response and tissue response is characteristic of coronavirus infection. As coronaviruses bind to the ACE2 receptor, it was proposed that ACE inhibitors (ACE-1) and angiotensin receptor blockers (ARBs) may be associated with increased severity of illness among COVID-19 patients due to ACE2 receptor upregulation. ${ }^{19,20}$ Researchers have also hypothesized that inhibition of the renin-angiotensin system and increased levels of ACE2 may have a protective effect in acute lung injury. In a recent study evaluating a cohort of 205 hospitalized patients with COVID-19 infection, although ACE-1 did not affect severity of illness, they did provide a beneficial effect. In this study, 37 (18\%) were on ACE-1, and a serial logistic regression analysis confirmed a significant decrease in the primary endpoints of death or admission to the intensive care unit (ICU) in those on ACE- 1 compared to patients not on ACE-I. ${ }^{21,22}$ The possible protective and treatment effectiveness of ARBs (losartan) is currently being evaluated in paired multicentered randomized double-blinded control clinical trials initiated at the University of Minnesota (ClinicalTrials.gov: NCT04311177 and NCT04312009).

\section{The Cytokine Storm and Secondary Hemophagocytic Histiocytosis}

A devastating, rapidly fatal cytokine storm may occur in coronavirus infections, resulting in secondary hemophagocytic histiocytosis ( $\mathrm{sHLH}$ ), characterized by multiorgan failure ( - Fig. 4). This cytokine storm is responsible for much of the problems encountered by patients with the SARS-CoV-2 infection because the storm is a hyperimmune response
CYTOKINE STORM IN COVID-19

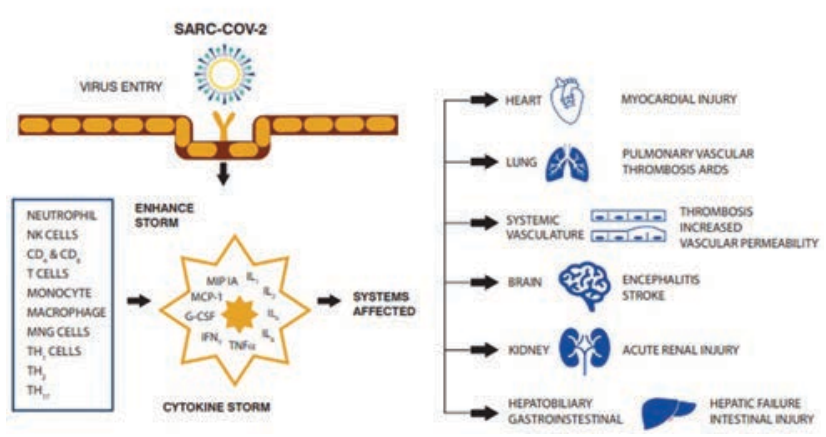

Fig. 4 The cytokine storm and secondary hemophagocytic histiocytosis. COVID-19, novel coronavirus disease 2019; SARS-CoV-2, severe acute respiratory syndrome-coronavirus- 2 .

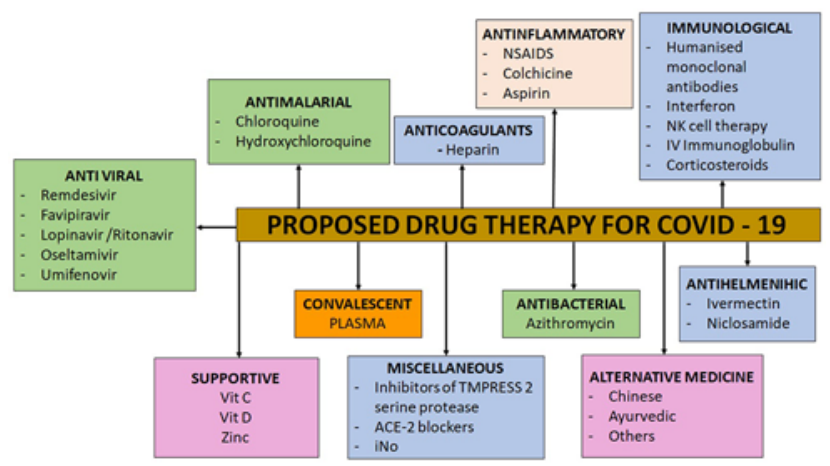

Fig. 5 Proposed drug therapy for covid-19. ACE2, angiotensinconverting enzyme 2; IV, intravenous; NK, natural killer; NSAID, nonsteroidal anti-inflammatory drugs;

to the virus resulting in a dysregulated, and accelerated expression of proinflammatory cytokines interleukin (IL)-2, IL-6, IL-8, and tumor necrosis factor (TNF). The predominant feature of sHLH includes reduced white blood cell counts, specifically lymphopenia, elevated serum ferritin levels, and severe acute respiratory distress syndrome (ARDS). High-ferritin levels are particularly dangerous because they suggest the presence of a significant hyperinflammatory response with their consequences on the lung. ${ }^{23,24}$ Thus, the treatment goals are to lower the consequences of the severe cytokine storm during severe COVID-19 pneumonia. Since entry of SARS-CoV-2 in cells is dependent on the connection of viral proteins $S$ with cellular receptors and activation of viral proteins by proteases of host cells, this could be one area of virus inhibition. Thus, factors that affect the clathrin-mediated endocytosis (a procedure that is partly regulated by microtubules remodeling) could potentially decelerate viral infection of cells. ${ }^{25}$ Colchicine is another drug that could be helpful because it has high bioavailability in granulocytes and monocytes. Its property to bind unpolymerized tubulin heterodimers, to form a stable complex effectively inhibits microtubule dynamics and is a nonselective inhibitor of the NLRP3 inflammasome, a major pathway element in the development of ARDS. ${ }^{26}$ The options for cytokine inhibition include possible corticosteroid or intravenous immunoglobulin administration. A randomized 
controlled trial with tocilizumab, an IL-6 blocker, is currently recruiting patients in China. ${ }^{27}$ Other treatment options are based on clinical findings and include heparin, serine protease inhibitors, such as ulinastatin, high-dose vitamin C, continuous renal replacement therapy (CRRT), and highvolume hemofiltration, as adjuncts in the care of critically ill patients with COVID-19 infection. Anti-IL-1 therapy with anakinra is being evaluated for patients with severe COVID-19 and sHLH. ${ }^{28}$ Evidence for a severe cytokine storm and mortality include reports by $\mathrm{Tu}$ et al. reporting higher levels of IL-6, C-reactive protein (CRP), and D-dimer levels in nonsurvivors. ${ }^{29,30}$ These findings offer information regarding the characteristics of severe COVID-19 infection and support further investigation regarding the use of immunomodulators. ${ }^{31}$ An expert consensus from China recommended cytokine clearance using an artificial liver blood purification (ALBP) systems. Plasma exchange, plasma absorption, and hemofiltration or plasma filtration have also been considered as alternative therapies. ${ }^{32,33}$

\section{Coronavirus and Hemoglobin Metabolism}

The pathological mechanism coronavirus causing COVID-19 remains enigmatic and mysterious. ${ }^{34} \mathrm{~A}$ report that looked at biochemical indices of 99 patients with COVID-19 demonstrated abnormal hemoglobin metabolism. ${ }^{35}$ This article revealed a decrease in the hemoglobin and neutrophil counts associated with elevated levels of serum ferritin, erythrocyte sedimentation rate (ESR), CRP, albumin, and lactate dehydrogenase (LDH).

\section{Exclusive Molecular Mechanism Explaining COVID-19 Expression ${ }^{33}$}

COVID-19 may not resemble the usual types of ARDS as seen in our routine critical care practice. The key pathogenic molecular step of SARS-CoV-2 is to attack the 1-beta chain of hemoglobin, attacking the porphyrins, dissociating, and releasing iron into the circulation. ${ }^{36}$ The ORF1ab, ORF10, and ORF3a proteins of the virus attack the heme on the 1-beta chain of hemoglobin. ${ }^{37}$ The virus binds deoxygenated hemoglobin readily compared to oxygenated hemoglobin resulting in resistant hypoxia coupled with rapid multiorgan failures. Following hemolysis of red blood cells, viral proteins bind to the hemoglobin and the virus enters the host cell via the spike-CD147 pathway. The virus interferes with the heme anabolic pathway and causes the disease. The free iron released into the circulation is toxic, causing powerful oxidative damage to the lungs. Free iron toxicity results in inflammation of alveolar macrophages that leads to characteristic changes seen on computerized tomographic scans of the lungs. ${ }^{38}$ The host attempts to compensate by accelerating hemoglobin synthesis consistent with improving hemoglobin values noted in these patients. ${ }^{39}$ Another compensatory mechanism that addresses the iron load is the increased ferritin levels documented in these patients. ${ }^{40}$ One cause for monocytosis seen in these patients may be the need for additional macrophages to engulf the excess iron load. The cause of lymphopenia may be that during white blood cell differentiation, the monocytes line is favored rather than lymphocytes line. As the iron load and hemoglobin increases, blood viscosity is also increased. This in combination with the hypercoagulable state may cause diffuse micro- and macrocirculatory thrombosis and the markedly elevated D-dimer levels seen in these patients. ${ }^{41}$ Postmortem studies have demonstrated that the ARDS picture is misleading and that the primary pathologic process is disseminated thrombosis. Mechanical ventilation without addressing this issue may cause more lung damage. Early and aggressive anticoagulation can be life-saving in these patients..$^{42}$ Chloroquine phosphate competes with porphyrin and binds to the viral protein, thereby inhibiting the viral protein's attacking the heme and the binding to porphyrin.

\section{Thrombogenesis and Coagulopathy in COVID-19}

A fulminant coagulopathy is described in patients with COVID-19 pneumonia. The hypercoagulable state is created by endothelial dysfunction leading to excessive thrombogenesis and inhibition of fibrinolysis. Hypoxia is a noted trigger of the procoagulant pathway leading to venous thrombosis. Postmortem examination of patients who died following a critical illness due to COVID-19 demonstrated microthrombosis in the pulmonary vessels. ${ }^{43,44}$ In a study of 183 consecutive patients with COVID-19, D-dimer and fibrin degradation products were significantly elevated, and the prothrombin and partial thromboplastin times were higher among nonsurvivors as compared to survivors. Among nonsurvivors, $71.4 \%$ had evidence of disseminated intravascular coagulation compared to $0.6 \%$ among survivors. ${ }^{45}$ The incidence of thrombotic events, including acute pulmonary embolism, deep vein thrombosis, acute ischemic stroke, acute myocardial infarction, and arterial embolism was evaluated in 182 COVID-19 patients admitted to three hospitals in the Netherlands. Thrombotic events were noted in 31\% of patients in this study, acute pulmonary embolism being the most common complication (82\%). Increasing age and the presence of coagulopathy were independent predictors of thrombotic events. ${ }^{46}$ Clinically significant coagulopathy with the presence of antiphospholipid antibodies was reported among three patients with COVID-19.44,47 In a retrospective, observational study of COVID-19 patients, who received anticoagulant therapy with unfractionated or low molecular weight heparin, was contrasted with those that had no anticoagulant treatment. A sepsis-induced coagulopathy score (SIC) was calculated based on platelet count, international normalized ratio (INR), and the sequential organ failure (SOFA) score. On multivariate logistic regression analysis, patients with an SIC score ${ }^{34}$ were treated with unfractionated or low molecular weight heparin had a significantly lower 28-day mortality compared to those who did not receive anticoagulant therapy. ${ }^{48}$ Thus, should anticoagulation be part of the therapy 
Table 1 Drugs that have been used/proposed for prevention and/or treatment of COVID-19 with the mechanism of action and current status as on June 1, 2020

\begin{tabular}{|c|c|c|}
\hline Drugs & Mechanism of action & Status of the clinical drug trial \\
\hline \multicolumn{3}{|l|}{ Antiviral } \\
\hline Remdesivir & $\begin{array}{l}\text { Antiviral interferes with virus RNA polymer- } \\
\text { ases to inhibit virus replication }\end{array}$ & $\begin{array}{l}\text { U.S. Food and Drug Administration } \\
\text { permitted emergency use authori- } \\
\text { zation on May 1, 2020. Clinical trials } \\
\text { have initiated in India }\end{array}$ \\
\hline Favipiravir & $\begin{array}{l}\text { Antiviral inhibits viral RNA polymerase, thus } \\
\text { interfering with viral replication }\end{array}$ & $\begin{array}{l}\text { Two clinical trials have achieved its } \\
\text { primary endpoint }\end{array}$ \\
\hline Lopinavir/ritonavir & Antiviral protease inhibitors & $\begin{array}{l}\text { Trials did not achieve it primary } \\
\text { endpoint }\end{array}$ \\
\hline Oseltamivir (Tamiflu) & $\begin{array}{l}\text { Antiviral drug approved for treatment of } \\
\text { influenza A and B. It targets the neurami- } \\
\text { nidase distributed on the surface of the } \\
\text { influenza virus to inhibit the spread of the } \\
\text { virus }\end{array}$ & Under evaluation \\
\hline Umifenovir (Arbidol) & $\begin{array}{l}\text { Antiviral impedes trimerization of SARS- } \\
\text { CoV-2 spike glycoprotein and inhibits host } \\
\text { cell adhesion like that of influenza virus } \\
\text { hemagglutinin }\end{array}$ & Under evaluation \\
\hline EIDD-2801 & $\begin{array}{l}\text { Antiviral incorporated during RNA synthesis } \\
\text { and then drives mutagenesis, thus inhibit- } \\
\text { ing viral replication }\end{array}$ & Prepared for trial \\
\hline CD24Fc & $\begin{array}{l}\text { Antiviral immunomodulator against inflam- } \\
\text { matory response }\end{array}$ & Under evaluation \\
\hline \multicolumn{3}{|l|}{ Antimalarial } \\
\hline Chloroquine/hydroxychloroquine & $\begin{array}{l}\text { Antimalarial endosomal acidification fusion } \\
\text { inhibitor anti-inflammatory activity }\end{array}$ & $\begin{array}{l}\text { Reduction of COVID-19 virus load } \\
\text { reported. Results from ongoing clini- } \\
\text { cal trials awaited. Its recommendation } \\
\text { for treatment has been withdrawn by } \\
\text { multiple agencies, due to potential } \\
\text { toxicity. Does not help postexposure }\end{array}$ \\
\hline \multicolumn{3}{|l|}{ Anticoagulants } \\
\hline Heparin & $\begin{array}{l}\text { Anticoagulants reverse the hypercoagula- } \\
\text { bility in severe cases }\end{array}$ & Proven trial \\
\hline \multicolumn{3}{|l|}{ Anti-inflammatory } \\
\hline Ibuprofen & NSAIDs anti-inflammatory & $\begin{array}{l}\text { Controversial: avoid if usual contrain- } \\
\text { dications present }\end{array}$ \\
\hline Colchicine & $\begin{array}{l}\text { Anti-inflammatory used in gout Inhibitory } \\
\text { effects on macrophages; for COVID-19 with } \\
\text { cardiomyopathy shown to reduce inflam- } \\
\text { mation in the cardiac myocytes }\end{array}$ & Under evaluation \\
\hline Anakinra & $\begin{array}{l}\text { Modified human IL-1 receptor antagonist } \\
\text { (IL-1RA) used in Rheumatoid arthritis }\end{array}$ & Under evaluation \\
\hline \multicolumn{3}{|l|}{ Immunological } \\
\hline Tocilizumab and sarilumab & Humanized mAb targeting IL-6 & Under evaluation \\
\hline Bevacizumab & Humanized mAb targeting VEGF & Under evaluation \\
\hline Baricitinib & $\begin{array}{l}\text { attenuates proinflammatory response by } \\
\text { inhibiting JAK and blocks virus entering } \\
\text { host cells through inhibiting AAK1 }\end{array}$ & Under evaluation \\
\hline Lenzilumab & $\begin{array}{l}\text { Humanized monoclonal antibody that } \\
\text { targets CSF2/GM-CSF }\end{array}$ & Under evaluation \\
\hline IFNs & $\begin{array}{l}\text { Immune enhancer inhibits viral RNA tran- } \\
\text { scription, protein translation and posttrans- } \\
\text { lational modification, thus suppress virus } \\
\text { replication }\end{array}$ & Under evaluation \\
\hline NK cell therapy & $\begin{array}{l}\text { Immune enhancer direct cytotoxicity and } \\
\text { immunomodulatory capability }\end{array}$ & Under evaluation \\
\hline IVlg & $\begin{array}{l}\text { Immune enhancer passive immunity and } \\
\text { anti-inflammatory effects }\end{array}$ & Under evaluation \\
\hline
\end{tabular}


Table 1 (Continued)

\begin{tabular}{|c|c|c|}
\hline Drugs & Mechanism of action & Status of the clinical drug trial \\
\hline Corticosteroids & $\begin{array}{l}\text { Reduces proinflammatory cytokines and } \\
\text { possess antifibrotic property }\end{array}$ & Low dose recommended \\
\hline $\begin{array}{l}\text { Cepharanthine/selamectin/mefloquine } \\
\text { hydrochloride }\end{array}$ & $\begin{array}{l}\text { Inhibit infection of simian Vero E6 cells } \\
\text { with pangolin coronavirus, whose } \mathrm{S} \text { protein } \\
\text { shares } 92.2 \% \text { amino acid identity with that } \\
\text { of SARS-CoV-2, prevents viral entry }\end{array}$ & Under evaluation \\
\hline \multicolumn{3}{|l|}{ Antihelminthic } \\
\hline Niclosamide and ivermectin & $\begin{array}{l}\text { Anthelmintic drug, virus replication } \\
\text { inhibitor }\end{array}$ & Under evaluation \\
\hline Nitazoxanide and tizoxanide & $\begin{array}{l}\text { Suppress proinflammatory cytokines in } \\
\text { PBMCs and IL-6 in vivo }\end{array}$ & Under evaluation \\
\hline \multicolumn{3}{|l|}{ Alternative medicine } \\
\hline \multicolumn{3}{|l|}{ Chinese medicines } \\
\hline LHQW & $\begin{array}{l}\text { TCM prevention and treatment for } \\
\text { influenzas }\end{array}$ & Under evaluation \\
\hline Xuebijing injection & $\begin{array}{l}\text { TCM endotoxin antagonist, anti-inflamma- } \\
\text { tory agent and anti-coagulant is used for } \\
\text { sepsis }\end{array}$ & Under evaluation \\
\hline \multicolumn{3}{|l|}{ Antibacterial } \\
\hline Azithromycin & $\begin{array}{l}\text { Antibacterial proven to be active in vitro } \\
\text { against Zika and Ebola viruses }\end{array}$ & $\begin{array}{l}\text { Positive data for the use, along with } \\
\text { hydroxychloroquine, in a COVID-19 } \\
\text { clinical trial. Not recommended in } \\
\text { combination with HCQ because of } \\
\text { cardiac arrhythmias }\end{array}$ \\
\hline \multicolumn{3}{|l|}{ Miscellaneous } \\
\hline Inhibitors of TMPRSS2 serine protease & $\begin{array}{l}\text { Cleavage and activation of the } S \text { protein of } \\
\text { SARS-CoV that is required for membrane } \\
\text { fusion and host cell entry is mediated by } \\
\text { TMPRSS2 }\end{array}$ & Under evaluation \\
\hline rhACE2 & $\begin{array}{l}\text { ACE2 blocker binds to virus S-protein, thus } \\
\text { protects host lungs } \\
\text { from virus attack }\end{array}$ & Under evaluation \\
\hline iNO & $\begin{array}{l}\text { Vasodilator potent and selective pulmonary } \\
\text { vasodilation and antimicrobial activity }\end{array}$ & Under evaluation \\
\hline Camostat mesilate (Foipan) & $\begin{array}{l}\text { synthetic serine protease inhibitors were } \\
\text { developed for the treatment of oral } \\
\text { squamous cell carcinoma, dystrophic } \\
\text { epidermolysis, exocrine pancreatic enzyme } \\
\text { inhibition, and chronic pancreatitis }\end{array}$ & Under evaluation \\
\hline Nafamostat mesilate (Buipel) & $\begin{array}{l}\text { A synthetic serine protease inhibitor } \\
\text { approved in Japan for the treatment of } \\
\text { acute pancreatitis, DIC and for anticoagula- } \\
\text { tion in extracorporeal circulation: It inhibits } \\
\text { MERS-CoV S protein-mediated viral mem- } \\
\text { brane fusion with TMPRSS2-expressing lung } \\
\text { Calu-3 host cells by inhibiting TMPRSS2 } \\
\text { protease activity }\end{array}$ & Under evaluation \\
\hline Dapagliflozin & $\begin{array}{l}\text { Used to treat type- } 2 \text { diabetes and, with } \\
\text { certain restrictions, type- } 1 \text { diabetes, adults } \\
\text { with heart failure with reduced ejection } \\
\text { fraction to reduce the risk of cardiovascular } \\
\text { death }\end{array}$ & Under evaluation \\
\hline Convalescent plasma & $\begin{array}{l}\text { Antiviral plasma from recovered patients } \\
\text { provides protective antibody }\end{array}$ & Early trials showing promising results. \\
\hline \multicolumn{3}{|l|}{ Supportive } \\
\hline Vitamin C & $\begin{array}{l}\text { boosts immunity by stimulating IFN pro- } \\
\text { duction, supplying lymphocyte prolifera- } \\
\text { tion and enhancing neutrophil phagocytic } \\
\text { capability }\end{array}$ & Under evaluation \\
\hline
\end{tabular}


Table 1 (Continued)

\begin{tabular}{|c|l|l|}
\hline Drugs & Mechanism of action & Status of the clinical drug trial \\
\hline Vitamin D & $\begin{array}{l}\text { induces secretion of antimicrobial peptides } \\
\text { and has immunomodulatory property }\end{array}$ & Under evaluation \\
\hline Zinc & $\begin{array}{l}\text { necessary for the immune system and has } \\
\text { antiviral activities }\end{array}$ & Under evaluation \\
\hline
\end{tabular}

Abbreviations: ACE2, angiotensin-converting enzyme 2; AAK1, adaptor associated protein kinase1; COVID-19, novel coronavirus disease 2019; DIC, disseminated intravascular coagulation; GM-CSF, granulocyte-macrophage colony stimulating factor; HCQ, hydroxychloroquine; IFN, interferon; IL, interleukin; iNO, inhaled nitric oxide; IVIg, IVIG=intravenous immunoglobulin; JAK, janus kinase; LHQW, Lianhua Qingwen; mAb, monoclonal antibody; MARS-CoV, Middle East respiratory syndrome-coronavirus; NSAIDs, nonsteroidal anti-inflammatory drugs; NK, natural killer; PBMCs, peripheral blood mononuclear cells; rhACE2, recombinant human angiotensin-converting enzyme 2; SARS-CoV-2, severe acute respiratory syndrome-coronavirus-2; $S$ protein; spike protein; TCM, traditional Chinese medicine; TMPRSS2, transmembrane protease/serine subfamily member 2; VEGF, vascular endothelial growth factor.

of patients with COVID-19. In view of a high incidence of thrombotic complications among patients with COVID-19, the International Society of Thrombosis and Haemostasis (ISTH) recommended administration of prophylactic low molecular weight heparin to all hospitalized patients with COVID-19 in the absence of active bleeding ensuring that platelet counts are greater than $25,000 / \mu \mathrm{L}$, regardless of the INR and activated partial thromboplastin time (APTT). This strategy is expected to reduce the incidence of a sepsis-like coagulopathy and prevent venous thromboembolism. ${ }^{49}$

\section{Drugs Used for COVID-19 Treatment}

According to the WHO, there are no available vaccines nor specific antiviral treatments for COVID-19. Care for patients with COVID-19 includes isolation, social distancing, hygiene, treatment of symptoms, supportive care, and institution of experimental protocols. On May 1, 2020, the United States gave Emergency Use Authorization to the antiviral remdesivir for people hospitalized with severe COVID-19. ${ }^{31}$ In March, WHO initiated the "SOLIDARITY Trial" to assess the treatment efficacy of four existing antiviral compounds which are favipiravir, remdesivir, lopinavir, and hydroxychloroquine (HCQ; or chloroquine [CQ]). ${ }^{50}$ On March 16, 2020 , the first clinical trial of a vaccine started that consists of a harmless genetic code copied from the virus that causes the disease at Seattle, United States. ${ }^{42}$ The following are the drugs suggested from literature searches against coronaviral disease ( - Table $\mathbf{1}$ ).

\section{Hydroxychloroquine}

There is contradictory evidence regarding the use of HCQ in COVID-19 infection. CQ used in treating malarial and autoimmune diseases, also confers considerable broad-spectrum antiviral effects even against SARS-CoV-2. HCQ is chemically like CQ but with lower ocular toxicity and has proven to be efficacious in containing SARS-CoV-2 in vitro. ${ }^{52,53}$

CQ phosphate inhibits terminal phosphorylation of ACE2, and HCQ elevates the $\mathrm{pH}$ in endosomes, which participate in virus cell entry. While HCQ may have benefit, it appears that additional investigation is required before committing to the routine use of HCQ against COVID-1954

\section{QT Interval (ECG) Prolongation with the Hydroxychloroquine-Azithromycin Combination}

Both HCQ and azithromycin are known to prolong the QT interval. Thus, patients on this combination require close cardiac monitoring. While the combination has been used successfully in some reports ${ }^{55}$ with in vitro efficacy of the combination. ${ }^{56}$ Chorin and associates describe the occurrence of significant QT prolongation including the occurrence of torsade de pointes when such a combination is used in the treatment of COVID-19. ${ }^{57}$ Thus, regular monitoring is required, especially among patients with renal dysfunction.

\section{Remdesivir}

The nucleoside analogue remdesivir has in vitro activity against SARS-CoV-2. ${ }^{58}$ It was originally developed to treat the Ebolavirus disease. It is an adenosine analogue which inserts into viral RNA chains, causing the premature breaking of the chains..$^{58}$ On May 1, 2020, the U.S. Food and Drug Administration granted Gilead Sciences, Inc. Emergency Use Authorization of remdesivir to be prescribed by licensed health care providers to treat adults and children hospitalized with severe COVID-19. ${ }^{59}$ Severe COVID-19 is defined as patients with an oxygen saturation $\left(\mathrm{SpO}_{2}\right) \leq 94 \%$ on room air or requiring supplemental oxygen or requiring mechanical ventilation or requiring extracorporeal membrane oxygenation (ECMO) and a heart-lung bypass machine. It was administered on a compassionate basis to 61 patients with COVID-19 who had an oxygen saturation of less than $94 \%$ on room air or required supplemental oxygen. Remdesivir was administered intravenously in a dose of $200 \mathrm{mg}$ on day 1 , followed by $100 \mathrm{mg}$ per day for 9 days. Clinical outcomes of 53 of the 61 patients were analyzed. At baseline, 30 patients (57\%) were invasively ventilated and 4 patients were on ECMO. The median follow-up period was 18 days. The level of the oxygen support device (ECMO, invasive mechanical ventilation, noninvasive ventilation, high-flow oxygen, or lowflow oxygen) could be successfully weaned in 36 patients (68\%). Seventeen of 30 patients (57\%) who were invasively ventilated were successfully liberated from the ventilator 
extubated. Twenty-five patients (47\%) had been discharged, and seven (13\%) had died at the time of follow-up. The mortality among invasively ventilated patients was $18 \%(6 / 34)$; mortality was 5\% (1/19) among those who did not receive invasive ventilation. ${ }^{60}$

\section{Favipiravir}

Fapinavir is an antiviral used against influenza. ${ }^{61}$ It is an oral pyrazine carboxamide derivative and guanine analogue developed by Toyama Chemical in Japan. Fapinavir selectively inhibits the RNA-dependent RNA polymerase of RNA viruses and induces lethal RNA transversion mutations, thereby producing a nonviable virus phenotype; this phenotype cannot bind to E2 glycoprotein and nucleocapsid and its binding energy to viral E protein, ORF7a, and ORF1ab is higher than porphyrin. The binding energy of $\mathrm{E}$ protein and favipiravir is more than 2,700 times the binding energy of porphyrin. The primary function of $\mathrm{E}$ protein is to help the virus enter host cells, which suggests that favipiravir acts by effectively preventing the viral entrance to human host cells. The WHO and the European Union has initiated clinical trials to test remdesivir, CQ and HCQ lopinavir/ritonavir (LPV-r), and LPV-r plus interferon (IFN) $\beta$-1a in COVID-19 patients worldwide in the SOLIDARITY Trial and in the DisCoVeRy Trial. ${ }^{62-64}$

\section{Lopinavir/Ritonavir with or without Interferon Beta-1A}

LPV-r is a specific protease inhibitor, fixed-dose combination medication used for the treatment and prevention of human immunodeficiency virus (HIV). Interferon-beta-1a is a cytokine in the interferon family used to treat multiple sclerosis (MS), produced by mammalian cells. Concomitant use of ritonavir and lopinavir could increase the plasma half-life of lopinavir through cytochrome P450 inhibition in the liver. Kim et al evaluated triple combination therapy with LPV-r, ribavirin, and IFN and has shown clinical effectiveness for MERS ${ }^{65} \mathrm{~A}$ randomized control trial (MIRACLE trial) was initiated to determine the therapeutic efficacy of LPV-r combined with interferon $\beta-1 \mathrm{~b}$ in patients infected with MERS-CoV. ${ }^{66}$ Studies observed that treatment with LPV-r compared to the standard care group was not associated with any change in time to clinical improvement, and mortality at 28 days was similar in both groups. Treatment with LPV-r did not reduce viral RNA load and SARS-CoV-2 RNA remained detectable at 28 days in $40.7 \%$ of the patients in the LPV-r cohort. However, patients in the LPV-r cohort demonstrated fewer complications, lessor need for invasive respiratory support, and had fewer secondary infections than did patients who did not receive LPV-r treatment. ${ }^{67}$

\section{Passive Antibodies}

The transfusion of convalescent plasma collected from patients who had recovered from COVID-19 to patients who were newly infected is being investigated in an active clinical trial initiated at Mayo Clinic (expanded access to convalescent plasma for the treatment of patients with COVID-19. ClinicalTrials.gov identifier: NCT04338360). Transferring purified and concentrated antibodies via transfusion of convalescent plasma is a method of passive immunization. Neutralization of the virus is expected with this therapy, antibody-dependent cellular cytotoxicity and subsequent phagocytosis may be possible. ${ }^{68}$

\section{Steroids}

Steroid administration has shown to benefit patients in the acute phase of the disease. ${ }^{69}$ The WHO does not currently recommend corticosteroid therapy in other viral diseases, such as for patients with dengue. One concern is that the glucocorticoid-mediated stimulation of the hypothalamic-pituitary-adrenal axis may drive lymphocytopenia or promote exaggerated proinflammatory responses which eventually worsen the pathogenic condition. ${ }^{69,70}$ According to the surviving sepsis guidelines, there was a reduced length of stay in the ICU and in turn reduced cost, with the use of low dose steroids. ${ }^{71,72}$

\section{Vaccine Trials}

A number of phase-1 vaccine trials are already underway. ${ }^{73-79}$

\section{Conclusion}

COVID-19 has been the infection of the century and has surprised clinicians and scientists with its structure and mechanism of infecting host cells, mimicking ARDS, and enveloping hemoglobin resulting in severe hypoxia with an intense immune response and multiorgan failure. The molecular docking technology identified the binding site of viral proteins to porphyrin. The virus infects cells with ACE2 receptors; the immune cells produce antibodies leading to immune-mediated hemolysis. The elevated levels of inflammation result in a cytokine storm, causing multiple organ failure. Lung damage occurs with thrombosis and leads to hypoxia. Various drug trials are ongoing to find the ultimate cure for this viral disease. Careful selection out of this extensive menu of drugs available, with adequate knowledge about their side effects and, most importantly, prevention being the ultimate "mantra" in the treatment of COVID-19.

Mr. Sigesh AK, Department of Marketing and Development, Narayana Health, Bangalore, Karnataka, India, for helping us with the editing of diagrams.

\section{Conflict of Interest}

None declared.

\section{Acknowledgment}

The authors would like to thank Mr. Pavan Krishna Kanchi, MS, Chemical engineering, PhD scholar, IIT, Guwahati, Assam, India, for helping in making the first draft of the manuscript.

\section{References}

1 Shi Y, Wang G, Cai XP, et al. An overview of COVID-19. J Zhejiang Univ Sci B 2020;21(5):343-360 
2 Nandraj S. Between 1918-19 Spanish flu and COVID-19, not much has changed. Available at: https://www.downtoearth. org.in/blog/governance/between-1918-19-spanish-flu-andcovid-19-not-much-has-changed-71425. Accessed August 10, 2020

3 Liang W, Liang H, Ou L, et al; China Medical Treatment Expert Group for COVID-19. Development and validation of a clinical risk score to predict the occurrence of critical illness in hospitalized patients with COVID-19. JAMA Intern Med 2020

4 Yadav PD, Potdar VA, Choudhary ML, et al. Full-genome sequences of the first two SARS-CoV-2 viruses from India. Indian J Med Res 2020;151(2, 3):200-209

5 Kirchdoerfer RN, Cottrell CA, Wang N, et al. Pre-fusion structure of a human coronavirus spike protein. Nature 2016;531(7592): 118-121

6 Walls AC, Tortorici MA, Bosch B-J, et al. Cryo-electron microscopy structure of a coronavirus spike glycoprotein trimer. Nature 2016;531(7592): :114-117

7 Beniac DR, Andonov A, Grudeski E, Booth TF. Architecture of the SARS coronavirus prefusion spike. Nat Struct Mol Biol 2006;13(8):751-752

8 Li F, Berardi M, Li W, Farzan M, Dormitzer PR, Harrison SC. Conformational states of the severe acute respiratory syndrome coronavirus spike protein ectodomain. J Virol 2006;80(14):6794-6800

9 Yan R, Zhang Y, Li Y, Xia L, Guo Y, Zhou Q. Structural basis for the recognition of SARS-CoV-2 by full-length human ACE2. Science 2020;367(6485) :1444-1448

10 Li F. Receptor recognition mechanisms of coronaviruses: a decade of structural studies. J Virol 2015;89(4):1954-1964

11 Li F. Structural analysis of major species barriers between humans and palm civets for severe acute respiratory syndrome coronavirus infections. J Virol 2008;82(14): 6984-6991

12 Wu K, Chen L, Peng G, et al. A virus-binding hot spot on human angiotensin-converting enzyme 2 is critical for binding of two different coronaviruses. J Virol 2011;85(11):5331-5337

13 Wu K, Peng G, Wilken M, Geraghty RJ, Li F. Mechanisms of host receptor adaptation by severe acute respiratory syndrome coronavirus. J Biol Chem 2012;287(12):8904-8911

14 Zheng M, Song L. Novel antibody epitopes dominate the antigenicity of spike glycoprotein in SARS-CoV-2 compared to SARS-CoV. Cell Mol Immunol 2020;17(5):536-538

15 Lan J, Ge J, Yu J, et al. Structure of the SARS-CoV-2 spike receptor-binding domain bound to the ACE2 receptor. Nature 2020;581(7807):215-220

16 Wang $\mathrm{Q}$ Zhang Y, Wu L, et al. Structural and functional basis of SARS-CoV-2 entry by using human ACE2. Cell 2020;181(4):894-904.e9

17 Srinivasan S, Cui H, Gao Z, et al. Structural genomics of SARS$\mathrm{CoV}-2$ indicates evolutionary conserved functional regions of viral proteins. Viruses 2020;12(4):E360

18 Brielle ES, Schneidman-Duhovny D, Linial M. The SARS-CoV-2 exerts a distinctive strategy for interacting with the ACE2 human receptor. Viruses 2020;12(5):E497

19 Perico L, Benigni A, Remuzzi G. Reply to the comment by Dr. Cure on "should COVID-19 concern nephrologists? Why and to what extent? The emerging impasse of angiotensin blockade" Nephron 2020;144(5):253-254

20 Perico L, Benigni A, Remuzzi G. Should COVID-19 concern nephrologists? Why and to what extent? The emerging impasse of angiotensin blockade. Nephron 2020;144(5):1-9

21 Javanmard SH, Heshmat-Ghahdarijani K, Vaseghi G. Angiotensin-converting-enzyme inhibitors (ACE inhibitors) and angiotensin II receptor blocker (ARB) use in COVID19 prevention or treatment: a paradox. Infect Control Hosp Epidemiol 2020;(e-pub ahead of print). doi:10.1017/ ice.2020.195
22 Bean D, Kraljevic Z, Searle T, et al. Treatment with ACEinhibitors is associated with less severe SARS-COVID-19 infection in a multi-site UK acute Hospital Trust. Available at: https://www.medrxiv.org/content/10.1101/2020.04.07.20056 788v1.full.pdf. Accessed August 10, 2020

23 Ruan Q, Yang K, Wang W, Jiang L, Song J. Clinical predictors of mortality due to COVID-19 based on an analysis of data of 150 patients from Wuhan, China. Intensive Care Med 2020;46(5):846-848

24 Liu L, Wei Q Lin Q et al. Anti-spike IgG causes severe acute lung injury by skewing macrophage responses during acute SARS-CoV infection. JCI Insight 2019;4(4):e123158

25 Stebbing J, Phelan A, Griffin I, et al. COVID-19: combining antiviral and anti-inflammatory treatments. Lancet Infect Dis 2020;20(4):400-402

26 Montealegre-Gomez G, Garavito E, Gomez-Lopez A, Rojas-Villarraga A, Parra-Medina R. [Colchicine: a potential therapeutic tool against COVID-19. Experience of 5 patients] (in Spanish) Reumatol Clin 2020;;doi:10.1016/j. reuma.2020.05.001

27 Chinese Clinical Trial Register (ChiCTR). Available at: http:// www.chictr.org.cn/searchprojen.aspx. Accessed August 10, 2020

28 Dimopoulos G, de Mast Q, Markou N, et al. Favorable anakinra responses in severe COVID-19 patients with secondary hemophagocytic lymphohistiocytosis. Cell Host Microbe 2020;28(1):117-123.e1

29 Tu H, Tu S, Gao S, Shao A, Sheng J. Current epidemiological and clinical features of COVID-19; a global perspective from China. J Infect 2020;81(1):1-9

30 Tu WJ, Cao J, Yu L, Hu X, Liu Q. Clinicolaboratory study of 25 fatal cases of COVID-19 in Wuhan. Intensive Care Med 2020;46(6):1117-1120

31 Update COVID-19: 03 June 2020. Available at: https://www. afro.who.int/news/update-covid-19-03-june-2020. Accessed August 10, 2020

32 Zhang Y, Yu L, Tang L, et al. A promising anti-cytokine-storm targeted therapy for covid-19: the artificial-liver blood-purification system. Engineering (Beijing) 2020

33 Ma J, Xia P, Zhou Y, et al. Potential effect of blood purification therapy in reducing cytokine storm as a late complication of critically ill COVID-19. Clin Immunol 2020;214:108408

34 Rothe C, Schunk M, Sothmann P, et al. Transmission of 2019nCoV Infection from an Asymptomatic Contact in Germany. N Engl J Med 2020;382(10):970-971

35 Chen N, Zhou M, Dong X, et al. Epidemiological and clinical characteristics of 99 cases of 2019 novel coronavirus pneumonia in Wuhan, China: a descriptive study. Lancet 2020;395(10223):507-513

36 COVID-19 disease: ORF8 and surface glycoprotein inhibit heme metabolism by binding to porphyrin. Available at: https:// chemrxiv.org/articles/COVID19_Disease_ORF8_and_Surface_ Glycoprotein_Inhibit_Heme_Metabolism_by_Binding_to_ Porphyrin/11938173/3. Accessed August 10, 2020

37 Wenzhong L, Hualan L. COVID-19: attacks the 1-beta chain of hemoglobin and captures the porphyrin to inhibit human heme metabolism. Available at: https://chemrxiv.org/articles/ COVID-19_Disease_ORF8_and_Surface_Glycoprotein_Inhibit_ Heme_Metabolism_by_Binding_to_Porphyrin/11938173/5. Accessed August 10, 2020

38 Liu K, Chen Y, Lin R, Han K. Clinical features of COVID-19 in elderly patients: A comparison with young and middle-aged patients. J Infect 2020;80(6):e14-e18

39 Lu G, Wang J. Dynamic changes in routine blood parameters of a severe COVID-19 case. Clin Chim Acta 2020;508:98-102

40 Terpos E, Ntanasis-Stathopoulos I, Elalamy I, et al. Hematological findings and complications of COVID-19. Am J Hematol 2020;95(7):834-847 
41 Spiezia L, Boscolo A, Poletto F, et al. COVID-19-related severe hypercoagulability in patients admitted to intensive care unit for acute respiratory failure. Thromb Haemost 2020;120(6):998-1000

42 Connors JM, Levy JH. COVID-19 and its implications for thrombosis and anticoagulation. Blood 2020;135(23):2033-2040

43 Wichmann D, Sperhake J-P, Lutgehetmann M, et al. Autopsy findings and venous thromboembolism in patients with COVID-19: a prospective cohort study. Ann Intern Med 2020(e-pub ahead of print). doi:10.7326/M20-2003

44 Ackermann M, Verleden SE, Kuehnel M, et al. Pulmonary vascular endothelialitis, thrombosis, and angiogenesis in COVID19. N Engl J Med 2020;383(2):120-128

45 Tang N, Li D, Wang X, Sun Z. Abnormal coagulation parameters are associated with poor prognosis in patients with novel coronavirus pneumonia. J Thromb Haemost 2020;18(4):844-847

46 Klok FA, Kruip MJHA, van der Meer NJM, et al. Confirmation of the high cumulative incidence of thrombotic complications in critically ill ICU patients with COVID-19: An updated analysis. Thromb Res 2020;191:148-150

47 Zhang Y, Xiao M, Zhang S, et al. Coagulopathy and antiphospholipid antibodies in patients with COVID-19. N Engl J Med 2020;382(17):e38

48 Tang N, Bai H, Chen X, Gong J, Li D, Sun Z. Anticoagulant treatment is associated with decreased mortality in severe coronavirus disease 2019 patients with coagulopathy. J Thromb Haemost 2020;18(5):1094-1099

49 Thachil J, Tang N, Gando S, et al. ISTH interim guidance on recognition and management of coagulopathy in COVID-19. J Thromb Haemost 2020;18(5):1023-1026

50 WHO launches global megatrial of the four most promising coronavirus treatments. Available at: https:// www.trialsitenews.com/who-launches-global-megatrial-of-the-four-most-promising-coronavirus-treatments/. Accessed August 10, 2020

51 Boulware DR, Pullen MF, Bangdiwala AS, et al. A randomized trial of hydroxychloroquine as postexposure prophylaxis for COVID-19. N Engl J Med 2020

52 Lim HS, Im JS, Cho JY, et al. Pharmacokinetics of hydroxychloroquine and its clinical implications in chemoprophylaxis against malaria caused by Plasmodium vivax. Antimicrob Agents Chemother 2009;53(4):1468-1475

53 Liu J, Cao R, Xu M, et al. Hydroxychloroquine, a less toxic derivative of chloroquine, is effective in inhibiting SARS-CoV-2 infection in vitro. Cell Discov 2020;6(1):16

54 Pastick KA, Okafor EC, Wang F, et al. Review: hydroxychloroquine and chloroquine for treatment of SARS-CoV-2 (COVID19) Open Forum Infect Dis 2020;7(4):a130

55 Million M, Lagier J-C, Gautret P, et al. Early treatment of COVID-19 patients with hydroxychloroquine and azithromycin: a retrospective analysis of 1061 cases in Marseille, France. Travel Med Infect Dis 2020;35:101738

56 Andreani J, Le Bideau M, Duflot I, et al. In vitro testing of combined hydroxychloroquine and azithromycin on SARS-CoV-2 shows synergistic effect. Microb Pathog 2020;145:104228

57 Chorin E, Wadhwani L, Magnani S, et al. QT interval prolongation and torsade de pointes in patients with COVID-19 treated with hydroxychloroquine/azithromycin. Heart Rhythm 2020(e-pub ahead of print). doi:10.1016/j.hrthm.2020.05.014

58 Gordon CJ, Tchesnokov EP, Feng JY, Porter DP, Götte M. The antiviral compound remdesivir potently inhibits RNA-dependent RNA polymerase from Middle East respiratory syndrome coronavirus. J Biol Chem 2020;295(15):4773-4779

59 Beigel JH, Tomashek KM, Dodd LE, et al. Remdesivir for the treatment of COVID-19 - preliminary report. N Engl J Med 2020
60 Grein J, Ohmagari N, Shin D, et al. Compassionate use of remdesivir for patients with severe COVID-19. N Engl J Med 2020;382(24):2327-2336

61 Delang L, Abdelnabi R, Neyts J. Favipiravir as a potential countermeasure against neglected and emerging RNA viruses. Antiviral Res 2018;153:85-94

62 Lê MP, Peiffer-Smadja N, Guedj J, et al; C-20-15 DisCoVeRy French Steering Committee. Rationale of a loading dose initiation for hydroxychloroquine treatment in COVID-19 infection in the DisCoVeRy trial. J Antimicrob Chemother 2020;dkaa191

63 Trial of Treatments for COVID-19 in Hospitalized Adults (DisCoVeRy). Available at: https://clinicaltrials.gov/ct2/show/ NCT04315948. Accessed August 10, 2020

64 Treatments for COVID-19: Canadian Arm of the SOLIDARITY Trial (CATCO). Available at: https://clinicaltrials.gov/ct2/ show $/$ NCT04330690? cond=solidarity+trial \&draw=2\&rank=1. Accessed August 10, 2020

65 Kim UJ, Won E-J, Kee S-J, Jung S-I, Jang H-C. Combination therapy with lopinavir/ritonavir, ribavirin and interferon- $\alpha$ for Middle East respiratory syndrome. Antivir Ther 2016;21(5):455-459

66 Arabi YM, Alothman A, Balkhy HH, et al; And the MIRACLE trial group. Treatment of Middle East Respiratory Syndrome with a combination of lopinavir-ritonavir and interferon- $\beta 1 b$ (MIRACLE trial): study protocol for a randomized controlled trial. Trials 2018;19(1):81

67 Cao B, Wang Y, Wen D, et al. A trial of lopinavir-ritonavir in adults hospitalized with severe COVID-19. N Engl J Med 2020;382(19):1787-1799

68 Casadevall A, Pirofski L-A. The convalescent sera option for containing COVID-19. J Clin Invest 2020;130(4):1545-1548

69 Russell B, Moss C, Rigg A, Van Hemelrijck M. COVID-19 and treatment with NSAIDs and corticosteroids: should we be limiting their use in the clinical setting? Ecancermedicalscience 2020;14:1023

70 Russell CD, Millar JE, Baillie JK. Clinical evidence does not support corticosteroid treatment for 2019-nCoV lung injury. Lancet 2020;395(10223):473-475

71 Alhazzani W, Møller MH, Arabi YM, et al. Surviving Sepsis Campaign: guidelines on the management of critically ill adults with Coronavirus Disease 2019 (COVID-19) Intensive Care Med 2020;46(5):854-887

72 Fadel R, Morrison AR, Vahia A, et al; Henry Ford COVID19 Management Task Force. Early short course corticosteroids in hospitalized patients with COVID-19. Clin Infect Dis 2020; ciaa601

73 Zhu F-C, Li Y-H, Guan X-H, et al. Safety, tolerability, and immunogenicity of a recombinant adenovirus type-5 vectored COVID-19 vaccine: a dose-escalation, open-label, nonrandomised, first-in-human trial. Lancet 2020;395(10240): 1845-1854

74 Lurie N, Saville M, Hatchett R, Halton J. Developing COVID-19 Vaccines at Pandemic Speed. N Engl J Med 2020;382(21):1969-1973

75 Lv H, Wu NC, Mok CKP. COVID-19 vaccines: knowing the unknown. Eur J Immunol 2020;50(7):939-943

76 Caddy S. Developing a vaccine for covid-19. BMJ 2020;369:m1790

77 Corey L, Mascola JR, Fauci AS, Collins FS. A strategic approach to COVID-19 vaccine R\&D. Science 2020;368(6494):948-950

78 Graham BS. Rapid COVID-19 vaccine development. Science 2020;368(6494):945-946

79 Thanh Le T, Andreadakis Z, Kumar A, et al. The COVID19 vaccine development landscape. Nat Rev Drug Discov 2020;19(5):305-306 